\title{
Quality Changes of Thermal Pasteurized Mussels (Mytilus galloprovincialis) During Refrigerated Storage at $4 \pm 1^{\circ} \mathrm{C}$
}

\author{
Şehnaz Yasemin Tosun (1), Didem Üçok Alakavuk (1), Şafak Ulusoy (i)
}

Cite this article as: Tosun, Ş.Y., Üçok Alakavuk, D., Ulusoy, Ş. (2018). Quality Changes of Thermal Pasteurized Mussels (Mytilus galloprovincialis) During Refrigerated Storage at $4 \pm 1^{\circ} \mathrm{C}$. Aquatic Sciences and Engineering, 33(4): 117-123.

Department of Seafood Processing Technology, Istanbul University, Faculty of Aquatic Sciences, İstanbul, 34134, Turkey

Submitted:

30.05.2018

Accepted:

27.07.2018

Available Online Date: 15.10.2018

Correspondence:

Şehnaz Yasemin Tosun

E-mail:

yasemin@istanbul.edu.tr

CCopyright 2018 by Aquatic

Sciences and Engineering

Available online at

ase.istanbul.edu.tr

\begin{abstract}
This study investigated the changes in quality of pasteurized mussels during storage at $4^{\circ} \mathrm{C} \pm 1^{\circ} \mathrm{C}$. Mussels (Mytilus galloprovincialis) were harvested from the Marmara Sea in March. The mussel flesh was packed with lemon juice, apple vinegar, finely chopped onion, salt, and black pepper. Then, all the packets were pasteurized $\left(\right.$ at $70^{\circ} \mathrm{C}$ for $8 \mathrm{~min}$ ) and stored for 21 days at $4^{\circ} \mathrm{C} \pm 1^{\circ} \mathrm{C}$. Results showed that the contents of protein, fat, and ash of pasteurized mussels were significantly higher $(p<0.05)$ than those of raw samples. The moisture content of mussels was significantly decreased $(p<0.05)$ after heat treatment. The meat yield of pasteurized mussels was $10.42 \%$. Sensory evaluation results indicated that the acceptability of pasteurized mussels at refrigerated storage was limited to 9 days. The TVB-N value of pasteurized samples exceeded the acceptability limit of 22-25 mg/100 $\mathrm{g}$ on the $9^{\text {th }}$ day. The TMA-N amount of pasteurized mussels remained lower than the acceptability limit during storage. The initial microbial load of the mussel samples reduced after the pasteurization process. This reduction was observed in the total mesophilic and psychrophilic bacterial count, with the yeast mold counts after pasteurization being 2.44 , 2.07, and $2.37 \log \mathrm{cfu} / \mathrm{g}$, respectively.
\end{abstract}

Keywords: Pasteurization, mussel, quality, ready-to-eat

\section{INTRODUCTION}

Nowadays, the trend towards ready-to-eat food at high quality makes thermal pasteurization applications important for food. Thermal pasteurization (usually below $100^{\circ} \mathrm{C}$ ) is a classic food preservation method that provides food safety, which reduces undesirable pathogenic vegetative cells, and deteriorates microorganisms, inactivates enzymes, and prolongs the shelf life of foods. Pasteurization used in the food industry does not kill all microorganisms in food. It is used in the food industry targeting pathogens that are important for public health and microorganisms that cause food spoilage. Today, pasteurization is regarded as a technology in which the desired food quality is preserved with minimum loss and pathogenic microorganisms are killed (Skipnes, et al., 2002; Peng et al., 2017).
Mussels are rich in nutrient components; also their economic value is high. They are very popular in many countries in terms of hunting and processing compared to other aquatic products. They are relatively inexpensive, contain high quality protein source, and are usually consumed raw, fresh, frozen and canned. The mussels have low fat and cholesterol content. it is also very rich in vitamins including, A, B1, B2, B6, B12 and C, free amino acids, trace elements (selenium, calcium, iron, magnesium and phosphorous) and glycogen. At the same time they have high $\mathrm{pH}$. This makes them a suitable substrate for the growth of microorganisms (Goulas, et al., 2005; Ovissipour, et al., 2013). On the other hand shellfish feed by filtering water. They accumulate various chemicals and microorganisms in their bodies (Vernocchi et al., 2007). Especially, raw and partially cooked 
molluscan shellfish (mussels, clams and oysters) are the most common tools of foodborne bacterial and viral diseases (Rippey, 1994).

Depending on all these properties, the mussel is a food that can deteriorate very quickly. Therefore, there is a need for appropriate storage technologies that prolong both shelf life and nutritional and sensory qualities. However, very little information and data are available on the quality changes that have taken place during the storage period, especially after heat treatment.

The purpose of this study, is to investigate the quality changes of mussel pasteurized with lemon juice, apple vinegar, onion, salt and black pepper during cold storage.

\section{MATERIAL AND METHOD}

\section{Mussels Supply and Handling}

Mussels (Mytilus galloprovincialis) were purchased from a wholesale fish market in Istanbul. The mussels were harvested from the Marmara Sea in March. Approximately 550 mussels were transferred to the laboratory in chilled polystyrene boxes within 60 minutes. Dead mussels were discarded after inspection. The average weight and length of the mussels were $23.94 \pm 6.80 \mathrm{~g}$ and $6.99 \pm 0.78 \mathrm{~cm}$. The mussels were washed and shucked by hand using a sterile shucking knife. Raw mussel flesh analysis was done immediately.

\section{Packaging and Pasteurization Process}

Approximately, twenty five (approx. 150g) mussel flesh was placed in a thermostable polyethylene-polyamide pouch $\left(\mathrm{O}_{2}\right.$ permeability of $160 \mathrm{~cm}^{3} / \mathrm{m}^{2}$ per $24 \mathrm{~h}$ at 23C, $0 \% \mathrm{RH}$ and water vapor permeability of $8.5 \mathrm{~g} / \mathrm{m}^{2}$ per $24 \mathrm{~h}$ at 38C, 90\% RH.) with lemon juice $(10 \mathrm{~mL})$, apple vinegar $(10 \mathrm{~mL})$, fine-chopped onion $(10 \mathrm{~g})$, salt $(0.5 \mathrm{~g})$ and black pepper $(0.5 \mathrm{~g})$. The packages were heat sealed under atmospheric air. Then, all packed samples were pasteurized $\left(70^{\circ} \mathrm{C}\right.$ for $\left.8 \mathrm{~min}\right)$ by using autoclave. A total 18 packages were prepared. Pasteurized samples were stored refrigerated $\left(4 \pm 1^{\circ} \mathrm{C}\right)$ conditions. After $0,6,9,12,15,18$ and 21 days randomly chosen two packages were removed for analysis.

\section{Yield Determination}

After thermal pasteurization, mussel meat was subsequently drained by placing on filter paper and then covered with another filter paper for five minutes. Consenquently the yield was compared with that from freshly unopened mussels. Mussels (25 pieces) yield are calculated by the following equation:

Yield (\%): [cooked mussel meat weight (g)/unopened mussel weight (g)] X 100 (Cruz-Romero et al., 2007; Bongiorno et al., 2015).

\section{Proximate Analyses}

The mussel samples were analyzed in triplicate for determination of the proximate composition: the lipid content of mussels was determined by the soxhelet method of the AOAC (1998a), the moisture content by the method of Mattissek et al. (1992), the ash content by the AOAC (1998b) method and total crude protein by the Kjeldhal method (AOAC, 1998C).

\section{Sensory Analysis}

The sensory attributes of pasteurized mussels were evaluated on each sampling day by ten trained panelists. Sensory analysis was performed in individual booths under controlled conditions of air circulation, light, temperature and humidity. Pasteurized mussels were evaluated on the basis of appearance, odor, texture and taste characteristics. The scale points were: 10-9=excellent; 8.9$8=$ very good; $7.9-6=$ good; $5.9-4=$ sufficient; < 4=unacceptable (Karl et al., 2001). The overall quality score was calculated as the average value of the score of the each attributes evaluated.

\section{Microbiological Analyses}

All microbiological analyses were performed in duplicate. Twenty five grams of mussel flesh for analysis was transferred aseptically to a sterile stomacher bag containing $225 \mathrm{~mL}$ of peptone from meat (Merck, 1.0214) (0.1\%) and homogenized in a stomacher (IUL Instrument, Spain) for 60 second. Appropriate serial dilutions were prepared (1:10 diluent, $0.1 \%$ peptone water). Total aerobic mesophilic bacteria (TAMB) and total aerobic psychrophilic bacteria (TAPB) were determined using Plate Count Agar (PCA, Merck, 1.05463) after incubation for $24-48$ hours at $37^{\circ} \mathrm{C}$ and for 10 days at $7^{\circ} \mathrm{C}$, respectively (Baumgard, 1986). Violet Red Bile Agar (Merck, 1.01406) and Violet Red Bile-Mug Agar (Merck, 1.04030) were used for the enumeration of total coliform bacteria and Escherichia coli after incubation at $30^{\circ} \mathrm{C} 18-24$ hours and $35^{\circ} \mathrm{C} 18-24$ hours, respectively (Feng et al., 2002). Dichloran Rose Bengal Chloramphenicol Agar (DRBC) (Merck, 1.00466) was used for the enumeration of yeast and mold (YM) after incubation at $25^{\circ} \mathrm{C}$ for 5 days (Tournas et al., 2001). Salmonella spp. determination was performed according to Andrews et al., (2007). Twenty five grams of mussel flesh was added to the $225 \mathrm{~mL}$ Lactose broth (Merck, 1.07661), and incubated at $37^{\circ} \mathrm{C}$ for $24-48$ hours. After the incubation, $0.1 \mathrm{~mL}$ homogenate was transferred into the 10 $\mathrm{mL}$ of Rappaport-Vassiliadis Broth (Merck 1.07700.500) and then incubated at $42^{\circ} \mathrm{C}$ for 24 hours for the selective enrichment. At the same time $1 \mathrm{~mL}$ homogenate was transferred in to $10 \mathrm{~mL}$ Tetrathionate Broth (Merck 1.05285) and then incubated for 24 hours at $43^{\circ} \mathrm{C}$. After the incubation, a loopful of broth cultures were streaked onto XLT4 (Merck 1.13919) and Bismut Sulfite Agar Base (Merck 1.05418). Plates were incubated at $35^{\circ} \mathrm{C}$ for $48 \mathrm{~h}$. After that, identification tests have been performed on suspected salmonella colonies. Mussel samples were analyzed for the presence of Vibrio spp. using FDA Bacteriological Analytical Manual (Kyasner and Depaola, 2004). Twenty five grams of mussel flesh was added to the $225 \mathrm{~mL}$ alkaline peptone water $(1 \% \mathrm{NaCl}+1 \%$ peptone from meat), after, a loopful of homogenate from alkaline peptone water was streaked on Thiosulphate Citrate Bile Salt Agar Base (TCBS, Merck 1.10263). Plates were incubated at $35^{\circ} \mathrm{C}$ for $18-24 \mathrm{~h}$ and identification tests have been performed on suspected colonies. Three agar plates per dilution were made in each medium.

\section{Chemical Analysis}

Chemical analyses for performed triplicate. For the $\mathrm{pH}$ analysis mussel samples were homogenized and diluted with distilled water at 1:1 (w/v) ratio. After that, the $\mathrm{pH}$ value of the mussel samples was measured with pH meter (Hanna pH 211 Microprocessor $\mathrm{pH}$ meter, Ann Arbor, MI) (Olafsdottir et al., 1997). 
Total volatile basic nitrogen (TVB-N) and trimethylamine nitrogen (TMA-N) analyses were carried according to the methods described by Schormüller (1968). Mussel samples were boiled with $\mathrm{MgO}$ (Merck, 1.05862) and vapor components held with $0.1 \mathrm{~N} \mathrm{HCl}$ (Merck, 1.00317). The amount of TVB-N was calculated after the titration with $0.1 \mathrm{~N} \mathrm{NaOH}$ (Merck, 1.06498). The results were expressed as milligrams of TVB-N per 100 grams of mussel flesh. For the estimation of TMA-N content of mussel flesh, $10 \mathrm{~g}$ samples were homogenized with 10\% trichloracetic acid solution (90 mL)(Merck, 100807) and homogenized samples were filtrated by Whatman No: 1 filter paper. After filtration, $4 \mathrm{~mL}$ filtrate was shaken with $10 \mathrm{~mL}$ toluene (Balmumcu Ltd.), $1 \mathrm{~mL} 20 \%$ formaldehyde (Merck, 1.04002) and $3 \mathrm{~mL} 50 \%$ potassium hydroxide (Carlo Erba, 362257). Following this, upper layer $(5 \mathrm{~mL})$ was separated and mixed with $0.02 \%$ picric acid ( $5 \mathrm{~mL}$ ). Absorbance was measured by a spectrophotometer (UV/VIS T80, PG Instruments Ltd) at $410 \mathrm{~nm}$. The TMA values were calculated from the standard curve and expressed as mg/100g samples.

\section{Statistical Analysis}

The average of the results from experimental studies was used for statistical analysis. The data were analyzed using IBM Statistical Package for the Social Sciences 21 software (SPSS Inc.; Chicago, IL, USA). Differences between means were analyzed by one way analysis of variance (ANOVA) followed by Tukey and Games-Howell tests. T-test was used to compare the results of the proximate composition. Differences at $(p<0.05)$ were considered significant.

\section{RESULT AND DISCUSSION}

In our study, pasteurized mussels had approximately $10.42 \%$ yield. Cruz-Romero et al., (2007), calculated the yield of traditional pasteurized oyster (at $75^{\circ} \mathrm{C}$ for $8 \mathrm{~min}$ ) range $1.5-15.5 \%$. Bongiorna et al., (2015), observed that, for Mytilus galloprovincialis maximum value of meat yield (cooked) in May (26.3\%) and minimum value of yields in January (12.5\%). In another study, Vernocchi et al., (2007), reported that meat yield (cooked) for Mytilus galloprovincialis ranged from $13.4 \%$ (July) and 25.2\% (January). Cavalheiro et al., (2013) reported the global weight loss of the blue mussels as $17.20 \%$ after vapor cooking. Meat yield of bivalve species may vary depending on gametogenic cycle of animals, water temperature, salinity, $\mathrm{pH}$, food availability and catching season (Orban et al., 2002; Yildiz et al., 2011).

Table 1. Proximate composition (\%) of raw and pasteurized mussels.

\begin{tabular}{lcc}
\hline & Raw Mussel & Pasteurized Mussel \\
\hline Protein & $10.61 \pm 0.09^{a}$ & $20.00 \pm 0.41^{b}$ \\
Fat & $2.11 \pm 0.10^{a}$ & $3.82 \pm 0.09^{b}$ \\
Moisture & $86.19 \pm 0.11^{a}$ & $73.46 \pm 0.20^{b}$ \\
Ash & $1.02 \pm 0.01^{a}$ & $2.18 \pm 0.03^{b}$ \\
\hline a-b: Different letters show significant differences $(p<0.05)$ \\
\hline
\end{tabular}

Proximate composition of raw and pasteurized mussel is shown in Table 1. The raw mussel meat had a moisture content of $86.19 \%$, protein $10.61 \%$, fat $2.11 \%$ and ash $1.02 \%$. Our results are similar to the results of many studies with Mytilus galloprovincialis (Khan et al, 2005; Fuentes et al., 2009; Özden et al., 2010; Ulusoy and Özden, 2011; Bongiorno et al., 2015). It is known that catching season, size, age, food availability, sex and reproductive cycle may influence the meat yield and nutritional composition of mussels (Orban et al, 2002; Stratev et al., 2017; Merdzhanova et al., 2018). The moisture, protein fat and ash contents of pasteurized mussel meat were $73.46,20.00,3.82$ and $2.18 \%$ respectively. The protein, fat, and ash contents of pasteurized mussels were significant higher $(p<0.05)$ than raw samples. Shelf life of stuffed mussels at $4^{\circ} \mathrm{C}$ in modified atmosphere packaging was studied by Ulusoy and Özden (2011). In their study, the protein, fat, and ash contents of stuffed mussels was found statistically significant higher after cooking as observed in our study. In this study, the moisture content of mussels significantly decreased $(p<0.05)$ after heat treatment, in agreement with data reported by Cruz-Romero et al. (2007), Ulusoy and Özden (2011) and Lekjing et al., (2017).

The $\mathrm{pH}$ value of pasteurized mussels during cold storage are shown in Table 2. Manousaridis et al., 2005, recommended the following $\mathrm{pH}$ scale points as a basis for evaluating the freshness of mollusks (oysters); 6.2-5.9=good; 5.8=off, 5.7-5.5= musty and 5.2 and below sour or putrid. In our study, $\mathrm{pH}$ value measured in raw mussel was 6.20 \pm 0.00 . Approximate $\mathrm{pH}$ values $(6.30,6.20$ and 6.20) were reported by Manousaridis et al., 2005, Masniyom and Benjama, (2007) and Bongiorno et al., (2018), respectively. In our study, initial pH of the sauce (lemon juice, apple vinegar, fine-chopped onion, salt and black pepper) was $2.55 \pm 0.03$ which is acidic. The $\mathrm{pH}$ value of samples decreased after treatment with lemon juice and vinegar, similar to results reported by others (Sallam et al., 2007; Cosansu et al., 2011; Cosansu et al., 2013). Bhunia et al., (2017), observed that a decrease in initial pH of blue mussels after treatment with red sauce (red tomato sauce, salt, and paprika)

The scores of sensory evaluation of pasteurized mussels are presented in Table 2. During the first 6 days, mussel samples were rated at $8.9-6$ scores. This range of points is defined as "very good" and "good". Acceptability scores for sensory quality of pasteurized mussel samples stored at $4 \pm 1^{\circ} \mathrm{C}$ decreased with time of refrigerated storage. The limit of acceptability of sensory quality was reached after $9^{\text {th }}$ day of storage. Pasteurized mussel samples were determined as unacceptable (2.20 \pm 0.93$)$ at the $12^{\text {th }}$ day of storage. In a similar study, Ulusoy and Özden, 2011, reported that the shelf life of stuffed mussel with air packed was $11^{\text {th }}$ day. In another study, sensory quality of cooked and chilled mussels without vacuum conditions unacceptable at $7^{\text {th }}$ day (Bongiorno et al., 2018).

In this study, initial TVB-N content of raw mussels were 17.52 \pm 1.94 $\mathrm{mg} / 100 \mathrm{~g}$. This value slightly higher than reported by previous studies (Masniyom and Benjama, 2007; Bongiorno et al., 2018). During refrigerated storage, TVB-N content increased in pasteurized mussels until end of storage (21 days), reached value of $29.24 \pm 0.38 \mathrm{mg} / 100 \mathrm{~g}$ (Table 2). The TVB-N content is often 
Table 2. Changes in sensory, $\mathrm{pH}, \mathrm{TVB}-\mathrm{N}$ and TMA-N values of raw and pasteurized mussels stored at $4 \pm 1^{\circ} \mathrm{C}$.

\begin{tabular}{|c|c|c|c|c|}
\hline Days & Sensory score & $\mathrm{pH}$ & TVB-N (mg/100g) & TMA-N $(\mathrm{mg} / 100 \mathrm{~g})$ \\
\hline 0 (Raw Material) & $7.66 \pm 0.27$ & $6.20 \pm 0.00$ & $17.52 \pm 1.94$ & $1.65 \pm 0.13$ \\
\hline 0 (Pasteurized samples) & $8.62 \pm 0.38^{a}$ & $4.65 \pm 0.05^{a}$ & $7.90 \pm 0.69 a$ & $3.39 \pm 0.00^{a}$ \\
\hline 7 & $7.02 \pm 0.62^{b}$ & $4.57 \pm 0.03^{\mathrm{ac}}$ & $21.92 \pm 0.98^{b}$ & $3.34 \pm 0.19 \mathrm{ab}$ \\
\hline 9 & $4.60 \pm 0.55^{c}$ & $4.65 \pm 0.07^{a}$ & $22.58 \pm 0.15^{b}$ & $3.37 \pm 0.17^{a}$ \\
\hline 12 & $2.20 \pm 0.93^{\mathrm{cd}}$ & $4.84 \pm 0.07^{b}$ & $22.24 \pm 0.67^{b}$ & $3.54 \pm 0.28^{\mathrm{ab}}$ \\
\hline 15 & $1.85 \pm 0.73^{d}$ & $4.43 \pm 0.06^{c}$ & $23.21 \pm 0.47^{b}$ & $3.40 \pm 0.00^{a}$ \\
\hline 18 & $1.40 \pm 0.35^{d}$ & $4.45 \pm 0.00^{c}$ & $24.35 \pm 0.29 c$ & $2.75 \pm 0.25^{\mathrm{ab}}$ \\
\hline 21 & $1.17 \pm 0.20^{d}$ & $4.54 \pm 0.04^{\text {ac }}$ & $29.24 \pm 0.38^{d}$ & $2.49 \pm 0.05^{b}$ \\
\hline \multicolumn{5}{|c|}{ a-d: Different letters in the same column show significant differences $(p<0.05)$} \\
\hline
\end{tabular}

Table 3. Changes in microbial counts of raw and pasteurized mussels stored at $4 \pm 1^{\circ} \mathrm{C}$.

\begin{tabular}{|c|c|c|c|}
\hline Days & TAMB (logcfu/g) & TAPB (logcfu/g) & YM (logcfu/g) \\
\hline 0 (Raw Material) & $5.59 \pm 0.02$ & $6.18 \pm 0.11$ & $6.30 \pm 0.02$ \\
\hline 0 (Pasteurized mussel) & $3.15 \pm 0.10^{a}$ & $4.11 \pm 0.01^{a}$ & $3.93 \pm 0.02^{a}$ \\
\hline 7 & $3.35 \pm 0.10^{\mathrm{ab}}$ & $2.20 \pm 0.17^{b}$ & $3.35 \pm 0.31^{\mathrm{ab}}$ \\
\hline 9 & $3.66 \pm 0.05^{b}$ & $2.10 \pm 0.17^{b}$ & $3.10 \pm 0.17^{b}$ \\
\hline 12 & $3.56 \pm 0.07^{a b}$ & $2.00 \pm 0.00^{b}$ & $3.10 \pm 0.17^{b}$ \\
\hline 15 & $3.20 \pm 0.17^{\mathrm{ab}}$ & $2.00 \pm 0.00^{b}$ & $2.10 \pm 0.17^{c}$ \\
\hline 18 & $3.41 \pm 0.10^{\mathrm{ab}}$ & $1.20 \pm 0.17^{b c}$ & $<100$ \\
\hline 21 & $3.47 \pm 0.00^{\mathrm{ab}}$ & $1.10 \pm 0.17^{c}$ & $<100$ \\
\hline
\end{tabular}

used as an index to evaluate the freshness and quality of seafood (Masniyom and Benjama, 2007). There are different views on acceptable limits in various literature. Kietzman et al., (1969) stated the TVB-N limit values in fish and fish products as follows; 25.00 $\mathrm{mg} / 100 \mathrm{~g}$ or lower TVB-N values; "very good", $30.00 \mathrm{mg} / 100 \mathrm{~g}$ TVB-N values; "good", 35.00 mg/100g TVB-N values; "marketable" and over 35.00 mg/100g TVB-N values; "unacceptable". Sikorski et al., (1990) cited TVB-N acceptability limit value for fatty fish is $20 \mathrm{mg} / 100 \mathrm{~g}$ and $17 \mathrm{mg} / 100 \mathrm{~g}$ for oyster. The limit of acceptability is suggested as $22-25 \mathrm{mg} / 100 \mathrm{~g}$ by Goulas et al., (2005), while it is $15 \mathrm{mg} / 100 \mathrm{~g}$ according to Erkan (2005). Ulusoy and Özden (2011), reported the TVB-N value of cooked stuffed mussels reached to $21.90 \mathrm{mg} / 100 \mathrm{~g}$ and exceeded the acceptable limit after nine days of storage. In our study, for pasteurized mussels the sensory score was approximately 4.60 on the $9^{\text {th }}$ day when the TVB- $N$ value reached $22.58 \pm 0.15 \mathrm{mg} / 100 \mathrm{~g}$. Panelists who performed sensory analysis evaluated mussel samples as "unacceptable" on the $12^{\text {th }}$ day. At the $12^{\text {th }}$ day of storage TVB-N content of mussel samples was $22.24 \pm 0.67 \mathrm{mg} / 100 \mathrm{~g}$. Our results were in accordance with that of Masniyom and Benjema, (2007) who reported a TVB- $N$ value of $20 \mathrm{mg} / 100 \mathrm{~g}$ for green mussel samples after 9 days of refrigerated storage. In our study, it would be more realistic to use the $22-25 \mathrm{mg} / 100 \mathrm{~g}$ TVB-N unacceptable limit value recommended by Goulas et al., (2005) for the mussel as compared with the value of $35.00 \mathrm{mg} / 100 \mathrm{~g}$ proposed for fish (Kietzman et al., 1969).

Trimethylamine is a non-protein nitrogenous compound, and is responsible for further fish degradation. TMA is formed by the reduction of Trimethylamine oxide (TMAO) caused by microbial action and possibly through the activity of endogenous enzymes. At the same time, it contributes to the characteristic ammonialike off-odor in fish spoilage (Sikorski et al., 1990; Gram and Huss, 1996; Goulas et al., 2005). TMA-N limit values for fish and other seafood were determined as follows. $4.00 \mathrm{mg} / 100 \mathrm{~g}$ TMA-N content; "good", 10.00 mg/100g TMA-N content; "marketable" and 12.00 mg/100g TMA-N content; "unacceptable" (Connell, 1980). Sikorski et al., (1990), suggested 5 to $10 \mathrm{mg}$ TMA-N per $100 \mathrm{~g}$ as the rejection limit. In our study, initial value of TMA-N in raw mussels was found $1.65 \pm 0.13 \mathrm{mg} / 100 \mathrm{~g}$. Approximate TMA-N values were reported by Kaba and Erkoyuncu, (2005) and Erkan, (2005). TMA-N value of pasteurized mussels did not exceed the limit value during storage period (Table 2).

Total viable count is an important criterion in assessing the quality of fresh and refrigerated seafood (Chouhan, et al., 2015). Changes in the microbiological count during cold storage were shown in Table 3. In our study, the initial total aer- 
obic mesophilic bacteria count in raw mussel was $5.59 \pm 0.02$ log cfu/g. Linton et al., 2003 also reported that total aerobic count for mussel samples was $5.00 \mathrm{log} \mathrm{cfu} / \mathrm{g}$. Total aerobic mesophilic bacteria count decreased $(3.15 \pm 0.10 \mathrm{log} \mathrm{cfu} / \mathrm{g})$ after pasteurization. Total bacterial count reached maximum load $(3.66 \pm 0.05 \mathrm{log} c f u / g)$ at the $9^{\text {th }}$ day of storage. In this study, total aerobic psychrophilic count in raw mussel was $6.18 \pm 0.11$ $\log \mathrm{cfu} / \mathrm{g}$. Similar, psychrotrophic count (>6 log cfu/g) was found by Linton et al., (2003) for mussel. After pasteurization, the total aerobic psychrophilic load was reduced $(4.11 \pm 0.01$ $\log \mathrm{cfu} / \mathrm{g}$ ). Total psychrophilic count of pasteurized mussels decreased steadily throughout the storage period (Table 3). Many studies have shown that various heat treatment application in aquatic products are effective in reducing total bacterial load (González-Fandos et al., 2004; Martínez-Alvarez, et al., 2009; Mol et al., 2012; Cosansu et al., 2011, Cosansu et al., 2013, De Lima et al., 2017 ; Doğruyol and Mol, 2017 ; Bongiorno et al., 2018). The results of our study are consistent with the findings of other researchers. The raw material had initial yeast-mold counts of $6.30 \pm 0.02 \mathrm{log} \mathrm{cfu} / \mathrm{g}$. Yeast-mold load of the raw material decreased (3.93 $\pm 0.02 \mathrm{log} c f u / g)$ after pasteurization process (Table 3 ). The counts of yeast-mold decreased throughout storage. The yeast and mold were not detected in the later days of storage. Velammal et al., (2017) did not detect fungal colonies throughout the storage period in cooked meat of brown mussel. Kilinc and Cakli $(2005 a, b)$ did not detect mold and yeast in pasteurized sardines during the cold storage. Vibrio spp. and Salmonella spp. were not detected in raw and pasteurized mussels in our study. Total coliform bacteria and Escherichia coli were found $5.28 \pm 0.07$ and $2.23 \pm 0.33 \mathrm{log} \mathrm{cfu} / \mathrm{g}$ in raw mussel, respectively. In our study, the pasteurization process eliminated total coliform bacteria and Escherichia coli in mussels. Thermal processing and refrigeration are important means of controlling these bacteria. Cosansu et al., (2011) and (2013) reported no growth of these bacteria in sous-vide fish.

\section{CONCLUSION}

In our study, the pasteurization process reduced the microbial load of the mussels and stabilized during the storage. Pasteurization was very effective on microbial flora. According to the TVB-N and sensory analysis results obtained in the study, the pasteurized mussel can be safely consumed for nine days storage at $4^{\circ} \mathrm{C}$.

Conflict of Interest: The authors have no conflicts of interest to declare.

\section{REFERENCES}

Andrews, W. H., Wang, H., Jacobson, A., and Hammack, T. (2007). Bacteriological analytical manual: Salmonella. Chapter 5. https://www.fda. $\mathrm{gov} /$ food/foodscienceresearch/laboratorymethods/ucm070149. htm (accessed 02.02.2018).

AOAC, (1998a). Official Method 948.15. Fat (crude) method in Seafood. Chapter 35. Fish and Other Marine Products, In "Official Methods of Analysis of AOAC International". Ed.by. P. Cunniff. Gaitherbury, Maryland USA.

AOAC, (1998b). Official Method 938.08. Ash of Seafood. Chapter 35. Fish and Other Marine Products, In "Official Methods of Analysis of AOAC International". Ed.by. P. Cunniff. Gaitherbury, Maryland USA.
AOAC, (1998c). Official Method 955.04. Nitrogen (total) in Seafood. Chapter 35. Fish and Other Marine Products, In "Official Methods of Analysis International". Ed.by. P. Cunniff. Gaitherbury, Maryland USA.

Baumgart, J. (1986). Lebensmittel tierischer herkunft, feinkosterzeugnisse, gefrorene, tiefgefrorene und getrocknete lebensmittel, fertiggerichte, hitzekonservierte lebensmittel, speiseeis, zucker, kakao, zuckerwaren, rohmassen. In J. Baumgart (Ed), Mikrobiologische Untersuchung von Lebensmitteln unter Mitarbeit von Jürgen Firnhaber (pp. 207). Behr's Verlag, Hamburg, Germany: Gottfried Spicher.

Bhunia, K., Ovissipour, M., Rasco, B., Tang, J. and Sablani, S.S. (2017). Oxidation-reduction potential and lipid oxidation in ready-to-eat blue mussels in red sauce: criteria for package design. Journal of Science of Food and Agriculture, 97:324-332. [CrossRef]

Bongiorno, T., lacumin, L., Tubaro, F., Marcuzzo, E., Sensidoni, A., and Tulli, F. (2015). Seasonal changes in technological and nutritional quality of Mytilus galloprovincialis from suspended culture in the Gulf of Trieste (North Adritic Sea). Food Chemistry, 173:355-362. [CrossRef]

Bongiorno, T., Tulli, F., Comi, G., Sensidoni, A., Andyanto, D. and lacumin, L. (2018). Sous-vide cook-chill mussel (Mytilus galloprovincialis): evaluation of chemical, microbiological and sensory quality during chilled storage $\left(3^{\circ} \mathrm{C}\right)$. LWT-Food Science and Technology, 91: 117124. [CrossRef]

Cavalheiro, D. Schmidt, F.C, Rodrigues, L.G.G., Siga, C., Leitempergher, F. and Laurindo, J.B. (2013). Processing of Perna Perna mussels using integrated process of cooking and vacuum cooling. Journal of Food Process Engineering, 36:192-201. [CrossRef]

Chouhan, A., Kaur, B.P. and Rao, S.P. (2015). Effect of high pressure processing and thermal treatment on quality of hilsa (Tenualosa ilisha) fillets during refrigerated storage. Innovative Food Science and Emerging Technologies, 29: 151-160. [CrossRef]

Connell, J. J. (1980). Control of Fish Quality. Farnham-England: Fishing New Books Ltd.

Cosansu, S., Mol, S., Ucok Alakavuk, D. and Ozturan, S. (2011). The effect of lemon juice on Bonito (Sarda sarda, Bloch, 1793) preserved by sous vide packaging. International Journal of Food Science and Technology, 46: 395-401. [CrossRef]

Cosansu, S., Mol, S., Ucok Alakavuk, D. and Ozturan, S. (2013). The effect of lemon juice on shelf life of sous vide packaged Whiting (Merlangius merlangus euxinus, Nordmann, 1840), Food Bioprocess Technology, 6: 283-289. [CrossRef]

Cruz-Romero, M., Kelly, A.L. and Kerry, J.P. (2007). Effects of high-pressure and heat treatments on physical and biochemical characteristics of oysters (Crassostrea gigas). Innovative Food Science and Emerging Technologies, 8(1): 30-38. [CrossRef]

Dogruyol, H. and Mol, S. (2017). Effect of irradiation on shelf life and microbial quality of cold-stored sous-vide mackerel fillets. Journal of Food Processing and Preservation, 41: 1-8. [CrossRef]

De Lima, M., Siga, C, Leitempergher, F., Lerin, L.A., Soares, L.S., Tosati, J.V., Rodrigues, N., B. and Monteiro, A.R. (2017). Mussel (Perna perna) processing by an alternative method and packaging under modified atmosphere to improve physicochemical and microbiological characteristics. Journal of Food Processing and Preservation, 41: 1-9.

Erkan, N. (2005). Changes in quality characteristics during cold storage of shucked mussels (Mytilus galloprovincialis) and selected chemical decomposition indicators. Journal of the Science of Food and Agriculture, 85: 2625-2630. [CrossRef]

Feng, P., Weagant, S.D. Grant, M.A., Burkhardt, W. (2002). Bacteriological Analytical Manual: Enumeration of Escherichia coli and the Coliform Bacteria. Chapter 4. 
Available from: https://www.fda.gov/Food/FoodScienceResearch/LaboratoryMethods/ucm064948.htm (accessed 02.02.2018).

Fuentes, A., Fernández-Segovia, I., Escriche, I. and Serra, J.A. (2009). Comparison of physico-chemical parameters and composition of mussels (Mytilus galloprovincialis Lmk) from different Spanish origins. Food Chemistry, 112: 295-302. [CrossRef]

Goulas, A.E., Choliara, I., Nessi, E., Kontaminas, M.G. and Savvaidis, I.N. (2005). Microbiological, biochemical and sensory assessment of mussels (Mytilus galloprovincialis) stored under modified atmosphere packaging. Journal of Applied Microbiology, 98: 752-760. [CrossRef]

Gram, L. and Huss, H. H. (1996). Microbiological spoilage of fish and fish products. International Journal of Food Microbiology, 33: 589-95. [CrossRef]

Gonzáles-Fandos, E., García-Linares, M.C., Villarino-Rodríguez, A., García-Arias, M.T. and García-Fernández, M.C. (2004). Evaluation of the microbiological safety and sensory quality of rainbow trout (Oncorhynchus mykiss) processed by the sous vide method. Food Microbiology, 21(2): 193-201. [CrossRef]

Kaba, N. and Erkoyuncu, i. (2005). Çeşitli şekillerde işlenen midyelerin (Mytilus galloprovincialis Lamarck, 1819) domuş depolama sırasında duyusal ve kimyasal kalitelerinin belirlenmesi. Atatürk Üniversitesi Ziraat Fakültesi Dergisi, 36(2):193-200.

Karl, H., Meyer, C., Münker, W. (2001). Vergleichende eislagerung von ausgenommenen und unausgenommenen schleien. Information für die Fischwirtschaft aus der Fischereiforschung 48(3): 138-143.

Kaysner, C, A. and DePaola, A. (2004). Bacteriological Analytical manual: Vibrio Chapter 9

Available from: https://www.fda.gov/Food/FoodScienceResearch/LaboratoryMethods/ucm070830.htm (accessed 02.02.2018).

Khan, M.A., Parrish, C.C. and Shahidi, F. (2005). Quality indicators of cultured Newfoundland Blue mussels (Mytilus edulis) during storage on ice: Microbial growth, $\mathrm{pH}$, lipid oxidation, chemical composition characteristics, and microbial fatty acid contents. Journal of Agricultural and Food Chemistry, 53(18): 7077-7073. [CrossRef]

Kilinc, B. and Cakli, S. (2005a). The determination of the shelf life of pasteurized and non-pasteurized sardine (Sardina pilchardus) marinades stored at $4^{\circ} \mathrm{C}$. International Journal of Food Science and Technology, 40: 265-271. [CrossRef]

Kilinc, B. and Cakli, S. (2005b). Determination of the shelf life of sardine (Sardina pilchardus) marinades in tomato sauce stored at $4^{\circ} \mathrm{C}$. Food Control, 16(7): 639-644. [CrossRef]

Kietzman, U., Priebbe, K., Rakow, D., Reichstein, K. (1969). Seefish als Lebensmittel, Paul Parey Verlag: Hamburg- Berlin.

Lekjing, S., Karrila, S. and Siripongvutikorn, S. (2017). Thermal inactivation of Listeria monocytogenes in Whole Oysters (Crassostrea belcheri) and Pasteurization Effect on Meat Quality. Journal of Aquatic Food Product Technology, 26(9): 1107-1120. [CrossRef]

Linton, M., Mc Clements, J.M.J. and Patterson, M. F. (2003). Changes in the microbiological quality of shellfish, brought about by treatment with high hydrostatic pressure. International Journal of Food Science and Technology, 38: 713-727. [CrossRef]

Manousaridis, G., Nerantzaki, A., Paleologos, E.K., Tsiotsias, A., Savvaidis, I.N. and Kontominas, M.G. (2005). Effect of ozone on microbial, chemical and sensory attributes of shucked mussels. Food Microbiology, 22(1): 1-9. [CrossRef]

Martínez-Alvarez, O., López-Caballero, M.E., Gómez-Guillén, M.C. and Montero, P. (2009). The effect of several cooking treatments on subsequent chilled storage of thawed deep water pink shrimp (Parapenaeus longirostris) treated with different melanosis-inhibiting formulas. LWT-Food Science and Technology, 42(8): 1335-1344. [CrossRef]
Masniyom, P. and Benjama, O. (2007). Effect of lactic, acetic and citric acids on quality changes of refrigerated green mussel, Perna viridis (Linnaeus, 1758). Songklanakarin Journal of Science and Technology 29(4): 1123-1134.

Mattıssek, R., Schnepel, M.F., Steıner, G. (1992). Lebensmittelanalytik, Grundzüge, Methoden, Anwendungen, Zweite, New York, NY: Springer Berlin Heidelberg. ISBN 3-540-54684-7.

Merdzhanova, A., Dobreva, D.A., Panayotova, V. (2018). Assessment of Proximate and Bioactive Lipid Composition of Black Sea Mussels (M. galloprovincialis) from Bulgaria. In: Biological Resources of Water, Edt: S., Ray. Available from: https://www.intechopen.com/ books/biological-resources-of-water (accessesd: 24.05.2018).

Mol, S., Ozturan, S., Cosansu, S. (2012). Determination of the quality and shelf life of sous vide packed Bonito (Sarda sarda, Bloch, 1793) stored at $4^{\circ} \mathrm{C}$ and $12^{\circ} \mathrm{C}$. Journal of Food Quality, 35:137- 143. [CrossRef]

Olafsdottir, G., Martinsdottir, E., Oehlensschlager, J., Dalgaard, P., Jensen, B., Undeland, I., Mackie, I.M., Henehan, G. \& Nielsen, H. (1997). Methods to evaluate fish freshness in research and industry. Trends Food Science and Technology 81: 258-265. [CrossRef]

Orban, E., Di Lena, G., Nevigato, T., Casini, I., Marzetti, A. and Caproni, R. (2002). Seasonal changes in meat content, condition index and chemical composition of mussels (Mytilus galloprovincialis) cultured in two different Italian sites. Food Chemistry, 77(1): 57-65. [CrossRef]

Ovissipour, M., Rasco, B., Tang, J., Sablani, S.S. (2013). Kinetics of quality changes in whole blue mussel (Mytilus edulis) during pasteurization. Food Research International, 53: 141-148. [CrossRef]

Özden, Ö., Ulusoy, Ş., Erkan, N. (2010). Study on the behavior of the trace metal and macro minerals in Mytilus galloprovincialis as a bioindicator species: the case of Marmara Sea, Turkey. Journal of Consumer Protection and Food Safety, 5: 407-412. [CrossRef]

Peng, J., Tang, J., Barrett, D.M., Sablani, S.S., Anderson, N. and Powers, J.R. (2017). Thermal pasteurization of ready-to-eat foods and vegetables. Critical factors for process design and effect on quality. Critical Reviews in Food Science and Nutrition, 57(14): 2970-2995. [CrossRef]

Rippey, S.R. (1994). Infectious Diseases Associated with molluscan shellfish consumption. Clinical Microbiology Reviews, 7(4): 419-425 [CrossRef]

Sallam, Kh.I., Ahmed, A.M. Elgazzar, M.M., Eldaly, E.A. (2007). Chemical quality and sensory attributes of marinated Pacific saury (Cololabis saira) during vacuum-packaged storage at $4^{\circ} \mathrm{C}$. Food Chemistry, 102: 1061-1070. [CrossRef]

Schormuller, J. (1968). Handbuch der Lebensmittel Chemie, Berlin, Heidelberg, New York: Springer- Verlag.

Sikorski, Z.E., Kolakowska, A., Burt, J.R. (1990). Postharvest biochemical and microbial changes. In: Z. E. Sikorski, (Ed) Seafood: Resources, Nutritional Composition, and Preservation, Postharvest Biochemical and Microbial Changes (pp.71). Boca Raton, Florida: CRC Press Inc.

Skipnes, D., Øines, S., Rosnes, J.T., Skåra, T. (2002). Heat transfer in vacuum packed mussels (Mytilus edulis) during thermal processing. Journal of Aquatic Food Product Technology, 11(3/4): 5-19. [CrossRef]

Stratev, D., Popova T., Zhelyazkov, G., Vashin, I., Dospatliev, L., Valkova, E. (2017). Seasonal Chages in Quality and Fatty acid composition of Black Mussel (Mytilus galloprovincialis). Journal of Aquatic Food Product Technology, 26(7): 871-879. [CrossRef]

Tournas, V., Stack, M.E., Mislivec, P.B., Koch, H.A. \& Bandler, R. (2001). Bacteriological Analytical Manual: Yeasts, Molds and Mycotoxins. Chapter 18. Available from: https://www.fda.gov/Food/FoodScienceResearch/LaboratoryMethods/ucm071435.htm/ (accessed 04.04.2018). 
Aquat Sci Eng 2018; 33(4): 117-123

Tosun et al. Quality Changes of Pasteurized Mussels

Ulusoy, Ş., Özden, Ö. (2011). Preservation of Stuffed Mussels at $4^{\circ} \mathrm{C}$ in Modified Atmosphere Packaging. Journal of Aquatic Food Product Technology, 20: 319-330. [CrossRef]

Velammal, A., Saritha, K., Immaculate, J.K., Jamila, P. (2017). Food Safety and shelf life of cooked meat of brown mussel, Perna perna (Linnaeus, 1758) stored under different temperatures. International Food Research Journal, 24(6): 2609-2615.
Vernocchi, P., Maffei, M., Lanciotti, R., Suzzi, G., Gardini, F. (2007). Characterization of Mediterranean mussels (Mytilus galloprovincialis) harvested in Adriatic Sea. Food Control, 18: 1574-1538. [CrossRef]

Yildiz, H. Berber, S. Acarli, A. and Vural, P. (2011). Seasonal variation in condition index, meat yield and biochemical composition of the flat oyster Ostrea edulis (Linnaeus, 1758) from the Dardanelles, Turkey. Italian Journal of Animal Science, 10: 22-26. [CrossRef] 